\title{
UPAYA MENINGKATKAN PEMAHAMAN KONSEP MATEMATIK DENGAN MODEL SNOWBALL THROWING PADA SISWA KELAS VIII SMP PLUS MATHLA'UL ANWAR CIBUAH
}

\author{
Ika Meika ${ }^{1}$, Asep Sujana ${ }^{2}$, Moh. Rizal Umami ${ }^{3}$ \\ Program Studi Pendidikan Matematika \\ FKIP Universitas Mathla'ul Anwar Banten \\ ikasep123@gmail.com
}

\begin{abstract}
Abstrak: Penelitian ini bertujuan untuk mengetahui peningkatan pemahaman konsep matematik dengan menggunakan model pembelajaran Snowball Throwing. Metode yang digunakan dalam penelitian ini adalah metode penelitian Tindakan Kelas (PTK) yang terdiri dari dua siklus dimana dalam setiap siklus terdapat tiga pertemuan dan satu kali tes. Model pembelajaran Snowball Throwing sudah terlaksana sesuai dengan proses pembelajaran yang diharapkan dikelas dengan memanfaatkan sumber-sumber belajar yang tersedian di sekolah dan memberikan pemahaman kepada siswa untuk lebih terbuka dan memberikan wawasan supaya memanfaatkan sumber belajar yang ada di lingkungan sekolah. Model pembelajaran Snowball Throwing dapat meningkatkan pemahaman konsep matematik siswa kelas VIII A SMP Plus Mathla'ul Anwar Cibuah pada materi pokok bahasan Operasi Pecahan Bentuk Aljabar. Peningkatan pemahaman konsep matematik siswa diperoleh dari hasil data pada kegiatan sebelum penelitian diperoleh nilai rata-rata mencapai $58 \%$ dan siswa yang mendapat kriteria tuntas adalah 7 siswa. Kemudian pada siklus I diperoleh nilai rata-rata mencapai $69 \%$ dan siswa yang mendapat kriteria tuntas adalah 16 siswa, dan pada siklus II mencapai nilai rata-rata 80,70\% dan siswa yang mendapat kriteria tuntas adalah 24 siswa. Dari hasil siklus yang telah dilakukan maka kegiatan penelitian tindakan kelas yang menggunakan model pembelajaran Snowball Throwing ini dikatakan berhasil. Karena suatu pembelajaran dikatakan berhasil apabila kriteria ketuntasan belajar mencapai 70\%. Ini terlihat pada siklus II yang mencapai nilai rata-rata 80,70\% dan siswa yang mendapat kriteria tuntas belajar adalah 24 siswa.
\end{abstract}

Katakunci: Pemahaman Konsep matematik, Snowball Throwing

\section{A. PENDAHULUAN}

Matematik merupakan salah satu pelajaran yang memegang peranan penting dalam dunia pendidikan. Mengingat betapa pentingnya matematik dalam dunia pendidikan, maka matematik dipelajari di setiap satuan pendidikan mulai dari sekolah dasar hingga ke perguruan tinggi. Akan tetapi matematik dikenal sebagai pelajaran yang sulit, membosankan dan menakutkan bagi siswa. Kesulitan dan ketakutan siswa terhadap pelajaran matematik ini disebabkan oleh sukarnya siswa memahami mata pelajaran matematik.

Keberhasilan pembelajaran matematik dapat dilihat dari keberhasilan siswa dalam kegiatan pembelajaran yaitu dari pemahaman, penguasaan materi, serta prestasi belajar siswa. Semakin tinggi pemahaman dan penguasaan materi maka semakin tinggi pula tingkat keberhasilan pembelajaran. 
Dari hasil pengamatan pengajaran matematik di SMP Plus Mathla'ul Anwar Cibuah Kec. Warunggunung Kab. Lebak di temukan bahwa nilai yang dicapai oleh siswa SMP masih rendah. Data yang diperoleh menunjukan nilai rata-rata siswa 55,0 di bawah nilai KKM yaitu 70. Hal ini di pengaruhi oleh faktor-faktor yang mempengaruhi pemahaman siswa khususnya pada siswa kelas VIII dalam pembelajaran matematik antara lain: 1) keaktifan siswa kelas VIII dalam mengikuti pembelajaran masih belum tampak, 2) siswa jarang memanfaatkan kesempatan dalam mengajukan pertanyaan untuk halhal yang belum dipahami, 3) rendahnya keaktifan siswa dalam mengerjakan soal-soal latihan pada proses pembelajaran.

Wina Sanjaya (2008: 120) mengemukakan bahwa pemahaman konsep merupakan kemampuan siswa dalam menuasai materi pembelajaran, sehingga siswa tidak sekedar mengetahui. Beberapa indikator pemahaman konsep diantaranya: mampu menerangka secara verbal mengenai apa yang telah dicapainya, mampu menyajikan situasi matematika dengan berbagai cara untuk mengetahui perbedaan, mampu mengelompokan objek-objek yang sesuai dengan persyaratan atau tidak sesuai persyaratan dalam membentuk konsep tersebut, mampu menerapkan hubungan antara konsep dan prosedur, mampu memberikan berbagai contoh dari konsep yang telah dipelajari dan menerapkan konsep secara algoritma.

Salah salah satu alternatif untuk mengatasi permasalahan di atas adalah dengan pemilihan model pembelajaran yang menarik dan dapat mangajak siswa agar dapat berperan aktif dalam proses pembelajaran. Pada dasarnya pembelajaran aktif adalah suatu pembelajaran yang mengajak siswa untuk terlibat aktif dalam belajar. Sehingga siswa terlibat langsung dalam proses pembelajaran yang melibatkan fisik dan mental. Salah satu model pembelajaran yang sesuai adalah model pembelajaran Snowball Throwing.

Menurut Jumanta Handatama (2014: 158) Snowball Throwing adalah model pembelajaran yang secara aktif melibatkan fisik, mental dan emosional siswa dengan melempar pertanyaan. Model Pembelajaran Snowball Throwing adalah model pembelajaran yang melatih siswa dalam menerima dan menyampaikan pesan temannya dalam satu kelompok.

Tujuan penelitian ini adalah untuk mengetahui seberapa jauh pengaruh model Snowball Throwing dalam meningkatkan pemahaman konsep matematik pada siswa kelas VIII SMP.

\section{B. METODE PENELITIAN}

Dalam penelitian ini penulis menggunakan metode kualitatif dalam bentuk Penelitian Tindakan Kelas (PTK). Dengan pusat penekanan pada upaya meningkatkan hasil pembelajaran siswa aktif. Penelitian ini lebih memfokuskan pada kerjasama siswa agar lebih aktif lagi dalam pembelajaran khususnya pelajaran matematika.

Menurut Kuswara Wihardit (2010: 196) menyatakan ada beberapa alasan pemilihan metode penelitian dengan menggunakan PTK adalah hal pertama dikerenakan PTK sangat kondusif untuk membuat guru menjadi peka 
dan tanggap terhadap dinamika pembelajaran di kelasnya. Kedua, Peningkatan kinerja guru dapat ditingkatkan. Ketiga, dengan melaksanakan tahap-tahap dalam PTK, guru mampu memperbaiki proses pembelajaran yang bisanya diterapkan. Keempat, pelaksanaan PTK tidak mengganggu tugas pokok seorang peneliti yang menjadi pengajar (guru) disekolah tempat ia meneliti, karena tidak perlu meninggalkan kelas pada saat Kegiatan Belajar Mengajar (KBM) berlangsung. Kelima dengan melaksanakan PTK pengajar menjadi lebih kreatif karena selalu dituntut untuk melakukan upaya-upaya atau inovasi sebagai implementasi dan adaptasi berbagai teori dan model pembelajaran serta bahan ajar yang dipahaminya.

Penelitian Tindak Kelas (PTK) yaitu sebuah kegiatan penelitian yang dilakukan di kelas sedangkan Supardi (2015: 115) mendefinisikan penelitian Tindakan Kelas merupakan suatu penelitian yang akar permasalahannya berasal dari apa yang terjadi dalam proses pembelajaran di kelas yang langsung dirasakan oleh guru. Penelitian ini difokuskan pada upaya meningkatkan pemahaman belajar matematika dengan model Snowball Throwing pada siswa kelas VIII di SMP Plus Mathla'ul Anwar Cibuah. Penelitian ini direncanakan terdiri dari dua siklus, setiap siklus direncanakan 3 kali pertemuan dan 1 kali pertemuan diberikan tes. Adapun beberapa ahli yang mengemukakan terdapat empat tahapan yang lazim dilalui yaitu: 1) Perencanaan, 2) Pelaksanaan, 3) Pengamatan, 4) Refleksi.

Populasi data penelitian adalah siswa kelas VIII SMP Plus Mathla'ul Anwar Cibuah. Adapun sampel Penelitian tindakan kelas ini dilakukan di kelas VIII A pada tahun pelajaran 2016/2017 yang siswanya berjumlah 30 siswa. Adapun jadwal penelitian adalah hari Selasa dan Jumat selama 2 jam pelajaran ( 2 x 40 menit). Penelitian ini dilakukan sebanyak dua siklus. Satu siklus terdiri dari 3 kali pertemuan dan satu kali tes. Sehingga pertemuan dua siklus adalah 6 kali pertemuan dan 2 kali tes.

Teknik pengumpulan data yang dilakukan pada penelitian ini diantaranya adalah tes, Observasi, Wawancara, Catatan Lapangan dan dokumen. Data yang dikumpulkan pada setiap kegiatan observasi dari pelaksanaan siklus penelitian dianalisis dengan cara mengamati, mencatat, dan melaporkan perkembangan siswa dalam proses belajar mengajar untuk melihat kecenderungan yang terjadi dalam kegiatan pembelajaran.

1. Hasil belajar, dengan menganalisis nilai siswa dalam mata pelajaran matematika yang dikategorikan dalam klasifikasi tinggi, sedang, rendah.

2. Aktivitas siswa dalam proses belajar mengajar matematika melalui model Snowball Throwing.

3. Implementasi pembelajaran melalui model Snowball Throwing, dengan menganalisis tingkat pemahaman siswa.

\section{PEMBAHASAN}

\section{Diskusi Temuan dan Pembahasan Hasil Evaluasi}

Berdasarkan hasil tindakan, observasi, evaluasi dan refleksi pada setiap siklus maka ditetapkan temuan dalam proses penelitian yaitu: 
a. Pada siklus I, proses pembelajaran belum sepenuhnya efektif. Pertemuan pertama guru belum dapat mengatur waktu yang baik. Hal ini dapat dilihat dari bertambahnya waktu yang diperlukan untuk membagi siswa kedalam kelompok. Terkadang pemantauan guru terhadap siswa dalam kelompok hanya terpaku pada kelompok tertentu saja. Sehingga saat ada kelompok lain yang membutuhkan bimbingan, guru tidak dapat memberikan pelayanan dengan baik. Siswa belum terbiasa dengan model pembelajaran, mengingat model pembelajaran ini merupakan hal yang masih baru bagi mereka. Hal ini dapat diamati dari siswa yang masing canggung saat berada dalam kelompoknya, akibatnya banyak siswa yang kurang aktif dalam mengerjakan soal-soal dalam Lembar Kerja Siswa (LKS) karena mereka mengharapkan jawaban dari teman kelompoknya. Hanya beberapa siswa yang dapat mempresentasikan hasil kerja kelompoknya.

b. Pada siklus II ini, proses belajar mengajar sudah efektif, siswa sudah terbiasa dengan model pembelajaran yang diterapkan, dari segi keaktifan siswa sudah mulai terbiasa dengan pembelajaran kelompok hal tersebut dipertegas dengan peningkatan hasil dari observasi siswa dan tes evaluasi siswa. Guru terlihat mampu mengorganisasikan waktu dengan baik serta mampu melaksanakan tugas pembelajaran dengan baik walaupun masih terdapat langkah-langkah pembelajaran yang belum terlaksana secara optimal. Siswa sudah kondusif dan lancar mengerjakan tes soal individu, hal ini dapat dilihat dari hasil tes evaluasi sudah mencapai indikator keberhasilan yang ditentukan. Dari hasil yang diperoleh dari siklus I ke siklus II maka dapat disimpulkan bahwa dengan menggunakan model pembelajaran Snowball Throwing dapat meningkatkan pemahaman konsep matematik siswa dan itu bisa dibuktikan dari hasil tes siswa yang menunjukan peningkatan dalam setiap siklusnya.

\section{Relevansi Model Pembelajaran Snowball Throwing dalam Peningkatan Pemahaman Konsep Matematik Siswa.}

Berdasarkan deskripsi hasil penelitian yang telah diuraikan sebelumnya, dapat diketahui bagaimana penerapan model Snowball Throwing mampu meningkatkan kemapuan pemahaman konsep matematik siswa kelas VIII A SMP Plus Mathla'ul Anwar Cibuah. Hal ini nampak dan dibuktikan berdasarkan data yang diperoleh dari hasil tes evaluasi siswa setiap siklusnya. Melihat data nilai tes evaluasi individu siswa bahwa terjadi peningkatan dari sebelum PTK ke siklus I, kemudian ke siklus II.

Melihat dari ketuntasan siswa, diperoleh data bahwa pada akhir siklus atau pada siklus II terdapat 24 siswa yang tuntas belajar dan 6 siswa yang belum tuntas belajar. 6 siswa yang belum tuntas sebenarnya mengalami peningkatan pembelajaran namun relatif rendah dari kriteria ketuntasan belajar, faktor utama kenapa 6 siswa ini belum tuntas dikarenakan dari kemampuan siswa tersebut, siswa belum sepenuhnya berjuang belajar, siswa tersebut masih kurang percaya diri dengan kemampuan yang mereka miliki dan siswa tersebut masih mengharapkan bantuan dari temannya bukan atas 
dasar kemampuannya sendiri. Untuk lebih jelasnya data peningkatan ketuntasan siswa dalam persentasi dapat dilihat dari Diagram 1 dibawah ini.

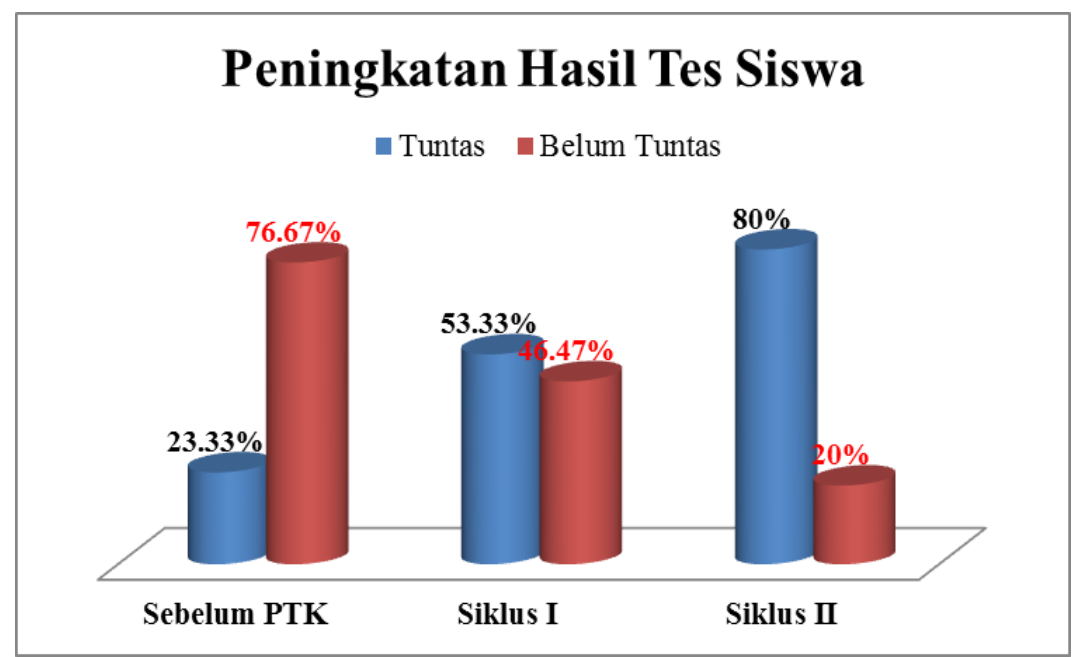

Diagram 1.

Pengkatan Hasil Tes Siswa Pada Ketuntasan Belajar

Dari Diagram di atas diperoleh bahwa:

1) Pada siklus I menunjukan persentase $53,33 \%$ siswa yang tuntas belajar cenderung mengalami peningkatan dari sebelum PTK yang perolehan persentase siswa yang tuntas adalah $23,33 \%$ dan siswa yang belum tuntas belajar dari $76,67 \%$ pada sebelum PTK menurun menjadi siswa menjadi siswa yang belum tuntas $46,47 \%$ pada siklus I.

2) Pada siklus II menunjukan persentase $80 \%$ siswa yang tuntas belajar sehingga mengalami peningkatan yang signifikan dari siklus I yang perolehan persentase siswa yang tuntas adalah 53,33\% dan siswa yang belum tuntas belajar dari $46,47 \%$ pada siklus I cenderung menurun menjadi siswa yang belum tuntas $20 \%$ pada siklus II.

Data di atas dari Diagram 1 dapat lebih dipahami dari hasil tes siswa pada ketuntasan belajar yang diuraikan secara keseluruhan supaya dapat lebih memperjelas peningkatan yang terjadi dalam setiap siklusnya. Data tersebut dapat dilihat dari tabel 1 di bawah ini

Tabel 1

Data Nilai Rata-rata Siswa Secara Keseluruhan

\begin{tabular}{cccc} 
Uraian & Sebelum PTK & Siklus I & Siklus II \\
\hline Tuntas & 7 orang & 16 & 24 \\
Belum Tuntas & 23 orang & 14 & 6 \\
\hline Rata-rata nilai & 58,0 & 69,0 & 80,70
\end{tabular}


Berdasarkan data di atas diperoleh setiap siklus mengalami peningkatan dimulai dari tuntas belajar dari sebelum penelitian ke siklus I dengan yang tuntas belajar berjumlah 7 orang meningkat ke 16 orang dengan nilai rata-rata dari 58,0 ke 69,0. Kemudian dari siklus I ke siklus II dengan yang tuntas belajar berjumlah dari 16 orang meningkat menjadi 24 orang dengan nilai rata-rata dari 69,0 menjadi 80,70. Dari hasil di atas dapat disajikan peningkatan nilai rata-rata yang digambarkan dalam Diagram 2 sebagai berikut.

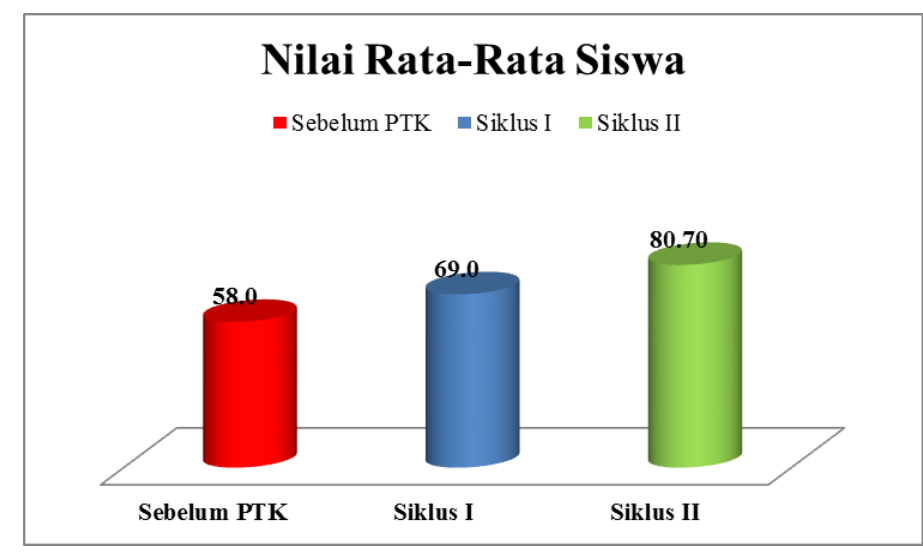

Diagram 2.

Nilai Rata-Rata Siswa

Berdasarkan Diagram 2 di atas, menunjukan adanya peningkatan nilai rata-rata siswa yang cukup baik, pada sebelum penelitian yaitu 58\% dan dari siklus I yaitu $69 \%$ maka peningkatannya sebesar $11 \%$.. Sementara pada siklus I yaitu $69 \%$ dan siklus II yaitu $80,70 \%$ maka peningkatan kemampuan pemahaman konsep sebesar $11,7 \%$.

Untuk melihat besarnya gain (peningkatan) dari sebelum PTK ke siklus I dan dari siklus I ke siklus II, disajikan dalam diagram berikut:

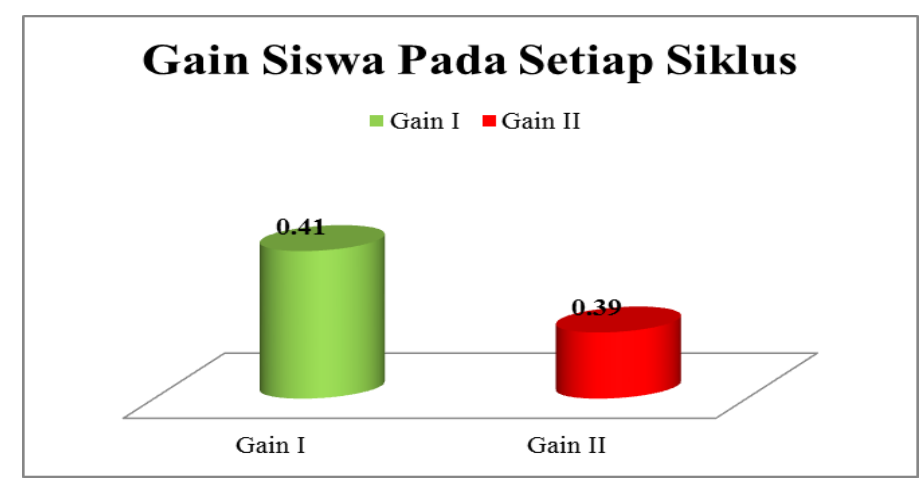

Diagram 3

Hasil Gain Siswa Pada Setiap Siklus 
Berdasarkan Diagram 3 bahwa hasil gain I di peroleh dari peningkatan nilai sebelum PTK ke siklus I dan gain II diperoleh dari peningkatan siklus I ke siklus II, perhitungannya dapat dilihat pada lampiran.

Dari diagram di atas terlihat peningkatan tersebsar terjadi pada gain I, hal ini disebabkan oleh beberapa faktor diantaranya:

1) Siswa yang sudah tuntas di siklus I motivasi belajar pada siklus II berkurang karena merasa sudah paham.

2) Pada siklus II guru sebagai peneliti lebih terfokus pada siswa yang belum tuntas di siklus I.

3) Siswa yang belum tuntas pada siklus I memiliki semangat yang lebih tinggi pada siklus II karena mereka diberi kesempatan untuk mempelajari dan mengejar ketertinggalan dengan siswa lain.

\section{KESIMPULAN}

Dengan demikian dari hasil penelitian dan pembahasan diperoleh kesimpulan bahwa model pembelajaran Snowball Throwing dapat meningkatkan pemahaman konsep matematik siswa kelas VIII A SMP Plus Mathla'ul Anwar Cibuah pada materi pokok bahasan Operasi Pecahan Bentuk Aljabar. Peningkatan pemahaman konsep matematik siswa diperoleh dari hasil tes tindakan setiap siklus, dimana siklus I mencapai nilai rata-rata 69,00 dan siklus II mencapai nilai rata-rata 80,70.

Kemudian model pembelajaran Snowball Throwing sudah terlaksana sesuai dengan proses pembelajaran yang diharapkan dikelas dengan memanfaatkan sumber-sumber belajar yang tersedia disekolah dan memberikan pemahaman dan wawasan baru kepada siswa untuk lebih terbuka. Model pembelajaran Snowball Throwing dapat meningkatkan aktivitas belajar siswa kelas VIII A SMP Plus Mathal'ul Anwar Cibuah pada materi pokok bahasan Operasi Pecahan Bentuk Aljabar, hal ini tergambar dari hasil observasi aktivitas siswa.

\section{E. DAFTAR PUSTAKA}

Hamdayama, Jumanta. (2014). Model dan Metode Pembelajaran Kreatif dan Berkarakter. Bogor: Ghalia Indonesia.

Sanjaya, Wina. (2008). Kurikulum dan Pembelajaran, Teori Praktek Pengembangan Kurikulum Tingkat Satuan Pendidikan (KTSP). Jakarta : Kencana.

Sudjana, Nana. (1989). Dasar-Dasar Proses Belajar Mengajar. Bandung: Sinar baru.

Sugiyono. (2013). Statistika Untuk Penelitian. Bandung: Alfabeta.

Suherman, Erman. (1992). Sistem Belajar Mengajar. Jakarta: Universitas Terbuka, Depdikbud.

Supardi. (2015). Penelitian Tindakan Kelas. Tangerang: Pustaka Mandiri.

Tumitah (2011). Model Pembelajaran Snowball Throwing Untuk Meningkatkan Hasil Belajar Matematika. Jakarta: Universitas Terbuka (tidak diterbitkan) 
Wihardit, Kuswaya dan Wardani IGAK. (2010). Penelitian Tindakan Kelas. Jakarta: Universitas Terbuka.

..(2015). Pedoman Penulisan Skripsi. Fakultas Keguruan dan Ilmu Pendidikan Universitas Mathla'ul Anwar Banten. 